within a given area. The measures for what is sometimes called 'internal plant protection' need not be co-ordinated between the different overseas countries; what is needed is that the most efficient methods for ensuring healthy crops be adopted, and this is a matter for each individual government. Usually, inspectors are appointed with powers to inspect crops and to prescribe specific treatment. The authority to destroy diseased plants may rest with the inspector but ranges up to a Minister; and similarly with powers of quarantine which may involve whole districts. Usually, compensation is payable at the discretion of the government, but this may be restricted to the destruction of healthy plants. Further, a grower may be compelled to destroy all dead plants of a crop, or may be forbidden to allow cultivated land to run wild unless the crop is destroyed.

A somewhat different aspect of the matter is seen in South Africa, where the majority of growers in an orchard area may request that the provisions of the Orchard Cleansing Act be applied to that area-and in Kenya, where a coffee plant may not be moved to another estate except under permit from the Director of Agriculture.

That special attention should be given to nurseries is obvious. It is usual for registered nurseries only to be allowed to offer plants for sale under an annual certificate of inspection and freedom from disease.

Most countries issue certificates of health for exports where needed, and occasionally no export is allowed without such a certificate. The Conference was of opinion that the system of certificates should be universally recognised, and drew up a form of certificate for approval and adoption.

Plant protection is given a more familiar bias in South Africa, where it is the declared policy to permit only imports of varieties or species that cannot be procured locally in adequate quantity and quality. Permission to import plants or cuttings is not given if seed will do. Here we have a similar regulation to the one which caused considerable uproar when passed by the United States a few years ago, and has meant so much 'dumping' of Dutch bulbs into Great Britain. The reference to seeds is interesting; for seeds seldom appear to be subject to import regulation. It is becoming recognised that seed-borne diseases are more important than was previously considered, and as the result of a discussion, the Conference suggested that the subject should be given increased attention throughout the Empire.

The need for a series of handbooks on the diseases of tropical and subtropical crops is much felt by those who are concerned mainly with two or three of these crops, for information is scattered over many periodicals. A subcommittee which was appointed to consider this drew up a list of eleven subjects and a provisional scheme of treatment, but it emphasised that " the series must be of outstanding merit, otherwise it would be preferable to drop the scheme altogether ".

The difficulties met with in tracing accounts of the diseases of a given crop are as nothing when compared with that of finding a way through the tangle of the literature of mycological taxonomy, and it is well worth noting that, in a Conference where the so-called practical side of mycology was rightly predominant, the first resolution passed concerned systematy. It was decided to refer to the International Botanical Congress the necessity for an abstracting journal of the world's literature on mycological taxonomy. This indicates a more general interest in pure mycology than has been apparent during recent years, and one which, if it is developed in the spirit of those men who have done most for phytopathology both at home and in the overseas Empire, will surely bring forth abounding results.

\title{
Search for an Oil-Pool in Kent.
}

\section{By Henry B. Milner.}

$\mathrm{O}^{\mathrm{s}}$ NE would have imagined that the history of oil exploration in the British Isles was sufficiently common knowledge to shake the faith of the most ardent believer in undiscovered resources, but apparently not. The attack on subWealden hydrocarbons has broken out afresh, this time in Kent, and the possibilities of great finds of oil are optimistically envisaged. We are informed that permission has been granted by the War Office for a well to be put down on land given over to the rifle ranges near Hythe, and that the operators responsible for the project anticipate a 'strike' at about $1000 \mathrm{ft}$.

It would be interesting to learn the technical grounds (if any) on which hopes of such a discovery are based. That competent geological opinion has been sought, or that this proposed venture is the result of closely reasoned evidence, it is difficult to believe. We thought that the myth of enormous natural gas reserves, of which
Heathfield, Sussex, was once considered to be an active indication, had been exploded long ago, so far as the Weald was concerned; maybe this present project has been conceived quite independently of any regard for what the concealed rocks of Sussex may or may not hold, though we can scarcely credit even elementary geological conceptions with disinclination to associate the two possibilities.

The geological column beneath Hythe cannot fail to be a most interesting and scientifically im. portant link in the chain of evidence of the preCretaceous rocks of the coastal margin of the Weald; to this extent a deep boring, carefully logged and sampled, is a most welcome happening. Presumably the operators in question have some idea of the rock succession they propose to traverse, and one is led at once to speculate on what data they rely for their forecast, not only of the occurrence of petroleum, but also of the rocks with which

No. 3132, VoL. 124] 
it is destined to be associated. They at least have one or two theories to work upon; it is not improbable that they have consulted some of the official records of deep borings in the neighbourhood, or the learned papers on the concealed rocks of the county. But even these can only serve as an approximate guide to circumstances, as underground conditions are obviously changing rapidly beneath this corner of Kent, and a great many things may happen to which existing evidence affords not the slightest clue. Hythe and its environs, in fact, constitute rather a blank spot in our present knowledge of subsurface tendencies, and it will be certainly an enlightening development if this boring goes to any great depth.

Arguing on the estimate of oil occurring at about $1000 \mathrm{ft}$., we can safely dismiss the possibility that Palæozoic pools are the object of the search; this is all to the good, since it saves any discussion on ' coal-oil ' relationship and will not be an encouragement to those who advocate the universal application of White's theory to reconsider the problems and deeper significances of the Kent coalfields. In point of fact, the supposed reservoir must be looked for much higher up in the geological scale, and we are forced back to our old friends the Portland Sand and underlying Kimmeridge Clay, the former to contain the pools, the latter (presumably) the mother-rock. Other horizons, the Oxfordian and Liassic clays, even if potentially oil-bearing rocks (which is more than doubtful), may be excluded either on account of possible absence or great depth at which they occur in a synclinal structure.

There is little doubt that the Kimmeridge Clay, as a formation, is mainly responsible for the bituminous manifestations in sub-Wealden rocks, especially the natural gas of Heathfield, and that where the Portlandian assumes a dominantly sandy character, it acts as a natural reservoir rock, a feature denied to the subjacent clay by the noteworthy absence of 'open' beds throughout its development. There is equally little doubt that small quantities of mineral oil do occur in association with these beds, but these are so insignificant as to be unworthy of more than passing mention. The conditions governing the formation and subsequent changes in the Kimmeridgian deposits were plainly biased to the production of oil-shale rather than liquid petroleum, with a minor accompaniment of a somewhat dry and very ' marshy' natural gas, conditions which can be paralleled in many other regions of the world. There is absolutely no technical evidence in favour of the possibility of this formation yielding oil in quantity either to indigenous reservoirs or to suitable containers above it; this applies to its development all over the country. It is, therefore, difficult to believe that it has changed its character beneath this small patch of Kent.

This, however, is not all. Even granting that the Kimmeridge Clay may have locally assumed the dignity of a prodigious oil-bearing motherrock, if there is one place where one cannot be quite certain of the immediately overlying succession, it would seem to be Hythe and Romney
Marsh. Beneath the normal Greensand of this locality the Wealden deposits occur, at least $500 \mathrm{ft}$. thick, increasing seawards by virtue of a synclinal attitude. The base of these beds may rest on anything from Purbeckian to Kimmeridgian : in other words, it is quite within the realms of probability that the Portlandian may be cut out altogether, as we know from the Elham boring, for example. In such an event, the prospective reservoir ceases to exist (since the lowermost beds of the Wealden are lithologically 'tight '), and any oil occurring in the Kimmeridge beds is still not much more mature than the idle globule.

There is, however, some evidence that the Portlandian deposits thicken westward beneath the Cretaceous cover, and this affords a chance of there being a small but suitable development beneath Hythe of the desired reservoir rock. A rough calculation from available data makes it apparent that, given the subsurface sequence to include the Portlandian, a $1000 \mathrm{ft}$. well would land just about in the middle of that formation, and this, supposedly, is the goal of the adventure.

Assuming, therefore, that the well-log ultimately demonstrates this anticipated sequence, we arrive at results which are familiar from many of the deep borings in Kent and elsewhere in the Weald, and there is not the least hope of the PortlandKimmeridge combination proving more attractive as regards oil at $\mathrm{Hythe}$ than at any other locality.

Throughout these notes we have taken but little account of structure except to mention casually a general synclinal tendency. There is little doubt that the Jurassic rocks in this part of Kent are thickening considerably as traced from north-east to south-west, one of the main arguments in favour of Lamplugh's sub-Wealden geosyncline. Although some kind of anticlinal structure is favoured with regard to oil accumulation in general, admittedly it is not an essential condition. There seems to be no suggestion of anticlinal developments in the subsurface rocks of Hythe; on the contrary, the relevant beds in connexion with this supposed oilpool have a decided seaward dip, if our reconstructions are correct; they are, in effect, part of the syncline. Now oil can occur in synclinal structures, but only under very precise conditions in which hydrological factors are peculiar; there is definite evidence that such hydrological circumstances are far from being realised in this part of England, hence we can hold out no hope of a unique synclinal accumulation. Thus does the conception of controlling structure prove equally discouraging.

It is, perhaps, a little unfortunate that the best site for the well should have been picked on Government ground, since it suggests that there may be some official backing for the enterprise. If this is so, we may at least plead for one important thing : that the boring be officially inspected from time to time and a record of the beds traversed compiled by competent authority, preferably the Geological Survey. If the oil be elusive, as oil so frequently is, then at least we shall by this means ensure the addition of the results of another deep boring to our knowledge of sub-Wealden geology.

No. 3132, VoL. 124] 